\title{
What 'ideas-about-science' should be taught in school science? A Delphi study of the expert community.
}

\author{
Sue Collins*, Jonathan Osborne*, Mary Ratcliffe**, Robin Millar ${ }^{+}$and Rick \\ Duschl*. \\ * King's College London, ** University of Southampton, ${ }^{+}$University of York
}

Paper presented at the Annual Conference of the American Educational Research Association April 10-14 2001 Seattle

The science that is encountered by adults, whether through the media or through work contexts, typically presents questions, decisions and the need for prioritisation. There is general agreement that, in order to respond to the questions, decisions and prioritisation, people need to know something about the functioning of science itself. We term this knowledge 'ideas-about-science'. However, there is little agreement about the content that might be included in school science curricula to address 'ideas-about-science'. The study presented in this paper therefore addresses a fundamental question: What ideas-aboutscience should be taught in school curricula? The question is addressed empirically, by the use of a three stage Delphi study. The sample for the study was a group of leading and acknowledged experts in science education, science, history, philosophy and sociology of science, science teaching, and activities to promote the public understanding of science. Five people were recruited from each of these groups, producing a sample of twenty five 'experts'.

In the first round, participants were asked what they thought students should be taught about the methods of science, the nature of scientific knowledge and the processes and practices of the scientific community. Their open-ended responses to these questions were then analysed and coded reflexively and iteratively to generate a set of 30 themes in the data. For each theme, a summary statement was developed that captured the broad intent of the participant's responses. These themes, and a selection of relevant anonymised arguments for their incorporation, were then fed back to the participants for comment and rating on a 5 point Likert scale in the second round. This process reduced the themes to a subset of seventeen. For the final round, these were then returned for comment, evaluation and a final rating, together with participants' arguments for their significance. Whilst some of the themes, and the ideas they represent, are already a feature of existing school science curricula, many others are not. The findings of this research therefore present an authoritative challenge as to whether existing practice in school science represents the views and values of the broad community engaged in science and science education. 


\section{Introduction}

This paper presents the findings of an empirical study conducted, using a Delphi technique, to answer the question 'What should be taught to school students about the nature of science?' The study was part of four projects of a funded network of research conducted by the University of York, the University of Leeds, the University of Southampton and King's College London whose principal aim was to develop and improve evidence-based practice in science education. This work, funded by the UK Economic and Social Science Research Council under the Teaching and Learning Programme, sought to provide empirical evidence of what the 'expert' community engaged with practising, communicating and teaching science thought was important for the average citizen to understand about science (as opposed to a knowledge of its content) at the end of their formal education.

The need for such a study was perceived to lie in the growing arguments for science education to provide a more effective preparation for citizenship (American Association for the Advancement of Science, 1993; American Association for the Advancement of Science, 1998; Millar \& Osborne, 1998). For whilst, there has been almost global acceptance that formal science education is an essential component of any young person's education, often from the ages of 7 to 16, there has been little attempt to develop a curriculum that is commensurate with such systemic reforms. Rather, science courses have been adapted from curricula whose roots lie in programmes that were essentially conceived as foundational studies for those who were to become the next generation of scientists. However, the core status of science can only be justified if it offers something of universal value to all and not the minority who will become the next generation of scientists. Such courses often gave scant or tacit treatment of the nature, practices and processes of science resulting in most pupils leaving school with naïve or limited conceptions of science (Driver, Leach, Millar, \& Scott, 1996). Yet it is this component which many have argued is essential for the education of the future citizen (Fuller, 1997; Irwin, 1995; Jenkins, 1997; Millar, 1996). However, contemporary academic scholarship would suggest that the nature of science is a contested domain with little consensus or agreement about a view that might be communicated in school science (Alters, 1997; Laudan, 1990; Taylor, 1996). This study sought, therefore, to determine the extent of any consensus amongst scientists, science communicators and science educators about those aspects of the nature of science that might be successfully communicated to school students.

The paper is in three parts: The first section briefly considers and reviews the many issues in the burgeoning body of academic literature that surround the nature of science and its teaching in school science; the second, and the major part, presents the methodology and its findings; the third discusses the conclusions that can be drawn from this work and their implications for the teaching of science.

\section{Teaching the Nature of Science: Difficulties and dilemmas}

Why teach the nature of science?

Science education attempts to wrestle with three conflicting requirements - what Collins (2000) terms the horns of a trilemma. On the one hand it wants to 
demonstrate the tremendous liberatory power that science offers - a combination of the excitement and thrill that comes from the ability to discover new knowledge, the freedom for individuals and societies to create their own knowledge, and the liberation from the shackles of received wisdom that science offers. Such attempts can be seen in the arguments of the advocates of the Nuffield course of the 1960s where school science was to offer the opportunity 'to be a scientist for a day'. More recently, it is embodied in the aspirations of the American educational reforms where it is explicitly stated that students at all grade levels 'should have the opportunity to use scientific inquiry and develop the ability to think and act in the ways associated with [scientific] inquiry' (National Academy of Science, 1995).

Yet science's mechanism for achieving such an aim is to rely on a dogmatic, and authoritarian education where students must accept what they are told as unequivocal, uncontested and unquestioned (Claxton, 1991) - the second horn of Collin's trilemma. Only when they finally begin practising as scientists will the workings of science become more transparent.

The outcome is that science education is, in a non trivial sense, science's worst enemy, leaving far too many pupils with a confused sense of the significance of what they have learnt and an ambivalent or negative attitude to the subject itself (Osborne \& Collins, 2000; Osborne, Driver, \& Simon, 1996). More importantly, however, such a science education ignores or neglects the third horn of Collin's trilemma - the requirement to provide its students with some picture of the inner workings of science - knowledge, that is, of science-in-the-making (Latour, 1985), and knowledge which is essential for the future citizen who must make judgements about reports about new scientific discoveries and applications. Contemporary society, it is argued (American Association for the Advancement of Science, 1989; Jenkins, 1997; Jenkins, 1998; Millar, 1996; Millar \& Osborne, 1998), requires a populace who have a better understanding of the workings of science thus enabling them to engage in a critical dialogue about the political and moral dilemmas posed by science and technology and arrive at considered decisions. Informed use by society of new developments in science will, for instance, require the ability to distinguish whether an argument is sound, and to differentiate evidence from hypotheses, conclusions from observations and correlations from causes.

Another imperative driving the need to teach more about science is the growing dominance of science and technology in our society. For science and technology pose questions which seem to require complex and specialised knowledge that only an elite possess. Yet contemporary pluralistic democratic ideology, a core commitment of Western societies, believes that all people should be able to contribute to the making of significant decisions (Nelkin, 1975). As the European White Paper on Education and Training (1995) argued:

'..this does not mean turning everyone into a scientific expert, but enabling them to fulfil an enlightened role in making choices which affect their environment and to understand in broad terms the social implications of debates between experts. There is similarly a need to make everyone capable of making considered decisions as consumers.' (p28)

Within science education, the response has been to argue for a curriculum that recognises the need to prepare pupils to critically engage with such issues, recognising both the strengths and the limitations of science. Millar, for instance, sees one of the 
major purposes of science education as 'equipping students to respond to socioscientific issues' and that 'this requires an understanding of the nature of scientific knowledge' (Millar, 1997:101). In the same volume, both Millar and Jenkins (1997) suggest that pupils should be provided with some insight into the difficulty of generating reliable and consensual understanding of the natural world. Likewise, Driver et al. (1996) argue that:

'Some explicit reflection on the nature of scientific knowledge, the role of observation and experiment, the nature of theory, and the relationship between evidence and theory, is an essential component of this aspect of understanding of science.' (Driver et al., 1996:14)

The outcome of such arguments and deliberations has led to a consideration of what other forms of knowledge and understanding, in addition to content knowledge, science education should seek to develop. Foremost in the literature have been arguments for a greater emphasis on the nature of science and its social practices.

\section{Arguments for Teaching about the Nature of Science}

Whilst knowledge of science entails knowledge of the scientific facts, laws, and theories, it also entails knowledge of the processes of science and its epistemic base. Matthews (1994) points elegantly to the latter as the missing dimension of science education arguing that:

To teach Boyle's Law without reflection on what "law" means in science, without considering what constitutes evidence for a law in science, and without attention to who Boyle was, when he lived and what he did, is to teach in a truncated way.

The overemphasis on 'what we know' at the expense of 'how we know' results in a science education which too often leaves students only able to justify their beliefs by reference to the teacher as an authority. Arguing from authority makes the pupil in the science classroom of the so-called contemporary Western society no different from those cultures that rely on the authority of oral assertion. In both cases the 'the propounders are deferred to as the accredited agents of tradition’ (Horton, 1971). Moreover, when confronted by new scientific claims, it leaves them without a functional understanding of the processes and practices necessary to evaluate the claim. And, if science and scientists are epistemically privileged, it is at best ironic, and at worst an act of 'bad faith' that the science education we offer does little to justify or explain why science is considered the epitome of rationality (Osborne, in press), and runs the risk of producing students who do not even perceive science as rational (Duschl, 1990). However, faced with the task of centrally defining a curriculum for all, policy makers have predominantly retained the traditional approach to science education and added marginal elements about the nature of science without much 'sense of coherence and underlying educational purpose' (Donnelly, 2001).

Abd-el-Khalik and Lederman (2000) make the important point that approaches to teaching the nature of science that assume it can be acquired implicitly, through a process akin to osmosis, is naïve. For the various images of science that have been constructed by the historians, philosophers and sociologists of science are the product of considerable collective and reflective endeavour. Just as nobody would expect a student to rediscover Newton's laws by observing moving objects, neither should we 
expect students to come to an understanding of science's nature simply by engaging in scientific practice. Therefore, the nature of science, they argue, must be explicitly taught as much at its content.

\section{Why has incorporating NOS in the school curriculum been a failed project?}

The nature of science in school science

Given the considerable attention devoted to exploring the significance and relevance of the history, philosophy and nature of science, it remains somewhat of a puzzle, therefore, that its consideration has remained such a marginal feature of most mainstream science education courses. There are several reasons and arguments as to why this might be so. Briefly these are:

Kuhn's (1970) observation that the history of the subject is of no import to the education of the future scientist. His or her concern is investigating the questions about nature that remain extant, not exploring how others have answered their own questions - answers which are now well understood and consensual knowledge within the scientific community.

Brush's thesis (1969) that much conventional teaching about the history of science is neither good science nor good history. It is not good science, as taking from the past is only of value if it offers something which is of significance to the present - which it rarely does. Moreover, it is not good history, as the myths and anecdotes that feature in science textbooks commonly reinforce a simplistic interpretation of the history of science, presenting the past in terms of present ideas and values, elevating in significance all incidents and work that have contributed to our current understanding, rather than attempting to understand the social context and the contingent factors which were significant to its production then.

Reichenbach's (1938) distinction between the context of historical discovery and the context of epistemological justification shows that the latter, the central concern of most science teachers, is a narrow focus of 'what we know' rather than 'how we know'.

Another fundamental difficulty identified within the literature by a variety of authors is that science teachers, themselves the products of such an archetypal education, are invariably left with a range of misconceptions or naïve understandings of the nature of science (Brickhouse, 1991; Hodson, 1993; Koulaidis \& Ogborn, 1995; Lederman \& Zielder, 1987). Various authors have argued that one of the necessary conditions of effective teaching is good knowledge and understanding of the content to be communicated (Shulman, 1986; Osborne \& Simon, 1996; Turner-Bissett, 1999). Likewise, it follows that teaching about the history, philosophy and nature of science requires a good knowledge and understanding of the body of scholarship that exists about the subject.

The contested nature of science

Abd-el-Khalick and Lederman (2000) argue that this work simply shows a failure of science teachers' own education to develop a 'valid understanding of NOS'. But what 
would such a valid understanding be? The one feature that emerges from an examination of the scholarship in the field of history and philosophy of science is that, if its intent was to establish a consensual understanding of the foundations of the practice of science, then it might be best characterised as a 'failed project' (Taylor, 1996). Notably, Laudan et al. (1986:142) were forced to conclude that:

the fact of the matter is that we have no well-confirmed general picture of how science works, no theory of science worthy of general assent. (p142)

Further evidence for a lack of any consensus comes from the work of Alters (1997) who surveyed the views of 210 members of the U.S. Philosophy of Science Association. Alters was forced to conclude from the 187 responses to his questionnaire that a ' minimum of 11 fundamental philosophy of science positions are held by philosophers of science today' and that, therefore, 'there is no one agreed-on philosophical position underpinning the existing NOS in science education.' Alter's conclusion was that the only legitimate position for the science education community was to acknowledge that no singular account exists and adopt a pluralistic approach to teaching about the nature of science. It should be noted, however, that the assumptions and methodological base of Alters work have been contested (Smith, Lederman, Bell, McComas, \& Clough, 1997). Moreover, an analysis of eight curriculum standards documents such as the Benchmarks for Scientific Literacy, National Science Standards, the California State Standards, and National Curricula in Australia, New Zealand, Canada, and England and Wales have shown that there does exist some consensus within the community concerned with science education about the elements of the nature of science that should be taught (McComas \& Olson, 1998).

Insofar as some or all of these elements might be contentious within the philosophical community, it is possible to argue that they represent a partial or simplified view of the nature of science. However, in that they represent elements that the community considers important aspects about science, they represent legitimate aspirations for the curriculum. Science education has, after all, commonly relied on vulgarised or simplified accounts as pedagogical heuristics for communicating a basic scientific understanding. And, if we are to ask science teachers to teach explicit aspects of the epistemic nature of science, then we as a community must come to some agreement about what those aspects might be (Duschl, Hamilton, \& Grundy, 1990). Our approach, then, in this research, has been to seek to establish empirically whether there is significant support within the expert community for an account of the nature of science, albeit reduced and contestable and potentially vulgarised, that might be offered to school students.

\section{Methodology}

This project has sought to determine the extent of consensus amongst 'experts' on what elements of the processes and practices of science should be essential components of the 5-16 curriculum. The method chosen for eliciting the 'expert' community's view was a 3 stage Delphi study (Clayton, 1997; Murry \& Hammons, 1995) similar to those used in other curriculum-based explorations (Haussler et al, 1980; Blair \& Uhl, 1993; Doyle, 1993; Smith \& Simpson, 1995). The Delphi method aims to improve group decision-making by seeking opinions without face-to-face 
interaction and is commonly defined as 'a method of systematic solicitation and collection of judgements on a particular topic through a set of carefully designed sequential questionnaires, interspersed with summarised information and feedback of opinions derived from earlier responses' (Delbecq et al., 1975). Three features characterise the Delphi method and distinguish it from other group interaction methods: anonymous group interaction and responses; multiple iteration of group responses with interspersed feedback; and the presentation of statistical analysis (Cypher \& Gant, 1983; Cochran, 1983; Uhl, 1983; Dailey \& Holmberg, 1990; Whitman, 1990).

The Delphi procedure seeks to establish the extent of consensus or stability in the community and typically ends after either consensus or stability of responses has been achieved. Brooks (1979) identified consensus as 'a gathering of individual evaluations around a median response, with minimal divergence' and stability or convergence was said to be reached when 'it becomes apparent that little, if any, further shifting of positions will occur' (p.378). The Delphi technique has four principal advantages felt to be important in gaining the considered opinions of these experts:

- it uses group decision-making techniques, involving experts in the field, which have greater validity than those made by an individual (Brooks, 1979);

- the anonymity of participants and the use of questionnaires avoids the problems commonly associated with group interviews: for example, specious persuasion or 'deference to authority, impact of oral facility, reluctance to modify publicised opinions and-band wagon effects’ (Martorella, 1991, p.84);

- consensus reached by the group reflects reasoned opinions because the Delphi process forces group members to consider logically the problem under study and to provide written responses (Murry \& Hammons, 1995);

- opinions using the Delphi method can be received from a group of experts who may be geographically separated from one another (Murry \& Hammons, 1995).

The main disadvantages of a Delphi study are seen as: the length of the process; researcher influence on the responses due to particular question formulation; and difficulty in assessing and fully utilising the expertise of the group because they never meet (Murry \& Hammons, 1995). The implementation of this Delphi study took full account of the perceived advantages and disadvantages.

For example, as science educators, we, (the researchers) have views on the teaching of the processes and practices of science. It was important that these views did not impinge on participants' responses. Therefore, very little guidance was given as to the expected content of responses in the first round of the Delphi study. In the second and third rounds, care was taken to ensure, as far as possible, participants' own words were returned and that participants had ample opportunity to comment on any interpretation in our conflation of their responses.

Commonly, the minimum number for a Delphi panel is considered to be ten (Cochran, 1983) with reduction in error and improved reliability with increased group size. However, Delbecq et al (1975) maintain that few new ideas are generated in a homogeneous group once the size exceeds thirty well-chosen participants. For this 
study, 25 experts were recruited, though the final sample was 23 . We define 'experts' in this context as those with acknowledged expertise in communicating, using or researching the processes and practices of science. Thus we sought views from leading scientists; science teachers; historians, philosophers and sociologists of science; science educators; and those engaged in the public understanding of science. Criteria used in selecting 'experts' included: membership of the Royal Society; books and publications; or national awards for teaching. The common element shared by the group was an interest in communicating ideas about science either in their writing, teaching or other work - all in essence having an experience of acting as 'knowledge intermediaries' between science and its publics. Appendix 1 contains a full list of the participants. There was no attrition in the group across the three rounds, reflecting the commitment of individuals to the process.

\section{The conduct of the Delphi study and the Analysis of the results}

\section{Round 1}

The first stage of the study, begun in January 2000, was an open-ended 'brainstorming'. Opinions were sought about what essential components should be taught about the following elements:

1. The nature of scientific knowledge e.g. predictive models, reliable/contested nature of evidence etc.

2. The processes and practices of the scientific community e.g. peer review, professional ethics etc.

3. The methods of science e.g. data collection, theory building etc.

For each component listed, participants were requested to give as clear a description of each idea as possible; to indicate a particular context where they thought a person might find the idea useful; and to state why such knowledge would be important for an individual to know.

This first round of the Delphi study elicited extensive comments from most participants. All these responses were coded, using NUDIST NVivo, reflexively and iteratively by the research team. Thirty themes emerged from this analysis and a summary was composed for each emergent theme, capturing the essence of participants' statements. Discussion among four members of the research team resulted in an agreed categorisation of the responses and the wording of theme summaries. To illustrate the result, figure 1 shows a summary of the justifications given for one of the themes and its presentation to participants in round 2. 

Figure 1: Outline of the justification of one theme from round 1 and its
presentation for round 2 - nature of scientific knowledge

\section{Theme - The tentative nature of scientific knowledge}

\section{Round 1}

\section{Justification}

Participants' statements for this theme highlighted the 'provisional', 'tentative' and 'evolutionary' nature of scientific knowledge. It was said to be provisional in the sense that science 'needs to go beyond the facts' (PS02) ${ }^{1}$, for example, 'if a prediction fails an appropriate scientific test, then the underlying rationale needs modification' (PU05). Scientific knowledge is tentative in that 'it is not fixed for all time' (SE03), but is in a state of continuous change, therefore, 'theories are the best we can do with the current state of knowledge' (S02). Pupils needed to recognise that scientific knowledge is 'the best kind of knowledge we have when it comes to understanding the natural world' (PS01), but theories may be 'falsified if wrong' (S06), modified, extended and revised in the light of new evidence. Whilst scientific knowledge evolved with improvements in techniques and technology, there remained 'patterns and laws that govern what happens in the universe' (T02). Theories were therefore 'open to debate, e.g. the earth exists - fact; but did the universe really start with the Big Bang?'(S03) and there continued to be 'mystery and beauty about fundamental scientific principles, e.g. periodic table, DNA, thermodynamics etc.' (T02)

\section{Round 2}

Theme title: The tentative nature of scientific knowledge

\section{Summary}

Pupils should recognise that scientific knowledge is provisional. Current scientific knowledge is the best we have but may be subject to further change given new evidence.

\section{Typical statements}

(a) Scientific knowledge is in a state of continuous change. Theories are the best we can do with the current state of knowledge.

(c) Theories can be falsified if wrong; they can be modified and extended if correct only in a limited region.

(d) That scientific knowledge is not fixed for all time because scientific ideas are adapted and revised in the light of new evidence.

(g) That scientific knowledge is tentative. Scientific knowledge depends on the available evidence and methods for gathering it. As technology makes more precision possible, so new evidence may be revealed, so ideas change. We should always regard scientific knowledge as the best we know at the moment and subject to change.

(i) They should be taught that scientific knowledge is the best kind of knowledge we have when it comes to understanding the natural world, but this does not make it perfect. They should understand that you have to get by with the best even if it is not perfect and often this will be scientific knowledge.

1 Codings refer to individuals but are not related to the order in which participants are listed in appendix 1 


\section{Round 2}

The Round 2 questionnaire presented the titles and summaries of the 30 themes, together with representative anonymised comments from individuals in Round 1 to clarify the nature of the theme. Participants were requested to rate the importance of each theme, as represented by the summary, on a 5 point Likert scale with a score of 5 representing the highest degree of importance. They were asked to show a justification for their rating and to make comments about the title of the theme and the accuracy of the summary in reflecting participants' meaning, and the representative statements.

Means and standard deviation for each theme using the rating given on the five-point scale were calculated (Table 1). A total of 8 themes had a mean of 4 or higher, indicating at this early stage that they were viewed by the panel as very important or important. Of these 8 themes, three themes showed standard deviations of $<1.0$, indicating a high level of consensus for these themes - experimental methods and critical testing, tentative nature of scientific knowledge, historical development of scientific knowledge.

Analysis of comments on proposed merging of themes and about the nature of the summary statements resulted in the merging of three pairs of themes, the splitting of one theme and modifications to summary statements of most themes. In illustration, figure 2 shows the changes between rounds 2 and 3 to the theme presented in figure 1 .

\section{Figure 2 The Nature of scientific knowledge: Revised version for round 3 and participants' comments from Round 2.}

\section{Round 3}

\section{Science and Certainty}

Summary

Pupils should appreciate why much scientific knowledge, particularly that taught in school science, is well-established and beyond reasonable doubt, and why other scientific knowledge is more open to legitimate doubt . It should also be explained that current scientific knowledge is the best we have but may be subject to change in the future, given new evidence or new interpretations of old evidence.

\section{Typical comments in support}

(a) It is not simply a matter of 'new evidence'. It is sometimes a matter of new perspectives. I would wish to stress this. Think not only of Galileo, Newton and Darwin, but of countless others (Fleming) in science and technology who have made progress by re-conceptualising a problem or even identifying the problem in the first place. I would want to find room for the incompleteness of scientific knowledge. The DNA structure is only part of the genetic code. We still do not know how proteins fold!

(b) Scientific knowledge is provisional not because it goes beyond the 'facts', but because the 'facts' will change and go beyond the science!

(c) Arguably the most essential of all, from the conceptual standpoint and public policy standpoint, provided it is linked well with Theme 1 (The Empirical Base of Scientific Knowledge) and Theme 2 (The Status of Scientific Knowledge and The Characteristics of Scientific Knowledge) 
Table 1 Themes for round 2 of the Delphi study, including the ratings given in round 2: (Themes are in the order resulting from Round 2)

\begin{tabular}{|c|c|c|c|}
\hline Theme title and summary & Mean & Mode & S.D. \\
\hline $\begin{array}{l}\text { Experimental methods and critical testing } \\
\text { Pupils should be taught that the experimental method permits the testing of ideas; that it } \\
\text { requires, in addition to imagination and ingenuity, a range of approaches; and that there } \\
\text { are certain basic techniques such as the use of controls which students should understand }\end{array}$ & 4.43 & 5 & 0.73 \\
\hline $\begin{array}{l}\text { Tentative nature of scientific knowledge } \\
\text { Pupils should recognise that scientific knowledge is provisional. Current scientific } \\
\text { knowledge is the best we have but may be subject to further change given new evidence. }\end{array}$ & 4.26 & 5 & 0.96 \\
\hline $\begin{array}{l}\text { Analysis and interpretation of data } \\
\text { Pupils should be taught that the practice of science is reliant on a set of skills required to } \\
\text { analyse and interpret data. Ideas in science do not emerge simply from the data but are } \\
\text { reliant on a process of measurement and interpretation which often requires sophisticated } \\
\text { skills. It is possible, therefore, for scientists to come to different interpretations of the } \\
\text { same data }\end{array}$ & 4.10 & 5 & 1.27 \\
\hline $\begin{array}{l}\text { Hypothesis and prediction } \\
\text { Pupils should be taught that scientists are engaged in developing hypotheses about the } \\
\text { nature of the world and testing those ideas. That this process is essential to the } \\
\text { development of scientific knowledge }\end{array}$ & 4.04 & 5 & 1.07 \\
\hline $\begin{array}{l}\text { Diversity of scientific method } \\
\text { Pupils should be taught science consists of a range of diverse methods and approaches } \\
\text { and there is no singular scientific method. Students need to be introduced to some of the } \\
\text { diversity }\end{array}$ & 4.04 & 4 & 1.07 \\
\hline $\begin{array}{l}\text { Historical development of scientific knowledge } \\
\text { Pupils should be taught some of the historical background and development of scientific } \\
\text { knowledge. Science has a long and complex history. }\end{array}$ & 4.00 & 4 & 0.95 \\
\hline $\begin{array}{l}\text { Creativity } \\
\text { Pupils should be taught that science is an activity that involves creativity and imagination } \\
\text { as much as any other human activity. That scientists are passionate and involved humans } \\
\text { that rely on inspiration and imagination and that this is an essential dimension of } \\
\text { scientific work }\end{array}$ & 4.00 & 5 & 1.13 \\
\hline $\begin{array}{l}\text { Science and questioning } \\
\text { Science is a process of asking questions of the natural world and this is an important } \\
\text { aspect of the work of a scientist }\end{array}$ & 4.00 & 5 & 1.28 \\
\hline $\begin{array}{l}\text { Observation and measurement } \\
\text { Pupils should be taught that observation and measurement are core activities undertaken } \\
\text { by scientists; that there is a limit to the accuracy of any measurement but there are ways } \\
\text { of limiting the uncertainty and increasing the confidence in the measurement }\end{array}$ & 3.90 & 5 & 1.02 \\
\hline $\begin{array}{l}\text { Specific methods of science } \\
\text { Pupils should be taught a range of methods that show how the analysis of data is a central } \\
\text { activity to the practice of science. This knowledge would assist their understanding of } \\
\text { scientific reports }\end{array}$ & 3.91 & 4 & 1.08 \\
\hline $\begin{array}{l}\text { Cumulative and revisionary nature of scientific knowledge } \\
\text { Pupils should be taught that scientific knowledge is cumulative, building on and } \\
\text { developing that which is already known. Good scientific theories have explanatory and } \\
\text { predictive power. }\end{array}$ & 3.90 & 4 & 1.04 \\
\hline $\begin{array}{l}\text { Moral and ethical dimensions in development of scientific knowledge } \\
\text { Pupils should be taught that developments in scientific knowledge are not value free, they } \\
\text { are subject to moral and ethical limitations }\end{array}$ & 3.87 & 5 & 1.33 \\
\hline $\begin{array}{l}\text { Types of knowledge } \\
\text { Pupils should be taught that there are different types of scientific knowledge, particularly } \\
\text { the difference between representations in school texts and that at the frontiers of science } \\
\text { research. }\end{array}$ & 3.74 & 4 & 1.05 \\
\hline $\begin{array}{l}\text { Features of scientific knowledge } \\
\text { Pupils should be taught that scientific knowledge produces reliable knowledge of the } \\
\text { physical world and has a number of attributes. Scientific knowledge aims to be general } \\
\text { and universal, it can be reductionist and counter-intuitive, and it has intrinsic cultural } \\
\text { value. Scientific explanations are based on models and representations of reality. }\end{array}$ & 3.74 & 4 & 1.36 \\
\hline
\end{tabular}


Table 1 continued

\begin{tabular}{|c|c|c|c|}
\hline Theme title & Mean & Mode & S.D. \\
\hline $\begin{array}{l}\text { Science and technology } \\
\text { Pupils should be taught that science and technology are interdependent. New technology } \\
\text { permits new measurements and new science develops new technology }\end{array}$ & 3.70 & 4 & 0.88 \\
\hline $\begin{array}{l}\text { Cause and correlation } \\
\text { Pupils should be taught that there are two types of distinctive relationship in science- } \\
\text { causal where there is a known mechanism relating an effect to a cause; and a correlation } \\
\text { where identified variables are associated statistically but for which there is no well- } \\
\text { established causal link }\end{array}$ & 3.70 & 5 & 1.39 \\
\hline $\begin{array}{l}\text { Cooperation and collaboration in development of scientific knowledge } \\
\text { Pupils should be taught that developments in science are not the result of individual } \\
\text { endeavour. They arise from group activity and collaboration, often of a multidisciplinary } \\
\text { and international nature }\end{array}$ & 3.61 & 5 & 1.47 \\
\hline $\begin{array}{l}\text { Developments in scientific knowledge are subject to peer review } \\
\text { Pupils should be taught that developments in scientific knowledge are critically reviewed } \\
\text { and may be authenticated and validated by members of the wider community }\end{array}$ & 3.60 & 4 & 1.26 \\
\hline $\begin{array}{l}\text { Common conceptions of science and risk } \\
\text { Pupils need to be taught that common public perceptions of science perpetuate a number } \\
\text { of myths which give erroneous impressions of the methods and nature of science. An } \\
\text { understanding of the basic concepts associated with risk and uncertainty }\end{array}$ & 3.59 & 3 & 1.26 \\
\hline $\begin{array}{l}\text { Contextual nature of science } \\
\text { Pupils should know that developments in scientific knowledge are not undertaken in } \\
\text { isolation, but may be shaped by particular contexts }\end{array}$ & 3.30 & 3 & 1.22 \\
\hline $\begin{array}{l}\text { The language of science } \\
\text { Pupils should be taught that science has a distinctive but common language. Scientific } \\
\text { language evolves with use. Terminology needs to be used with care, with meanings clearly } \\
\text { explained. }\end{array}$ & 3.30 & 3 & 1.05 \\
\hline $\begin{array}{l}\text { Science as a human, collaborative activity } \\
\text { Pupils should be taught that the production of scientific knowledge is a human activity } \\
\text { undertaken both by individuals and groups. Any new knowledge produced is generally } \\
\text { shared and subject to peer review. Although scientists may work as individuals they } \\
\text { contribute to the communal generation of a common, reliable body of knowledge. }\end{array}$ & 3.30 & 4 & 0.98 \\
\hline $\begin{array}{l}\text { Reporting scientific findings } \\
\text { Pupils should be taught that scientists use distinctive forms of communication for } \\
\text { reporting results which are reliant on a range of different genres and semiotic modes }\end{array}$ & 3.22 & 4 & 1.31 \\
\hline $\begin{array}{l}\text { Constraints on the development of scientific knowledge } \\
\text { Pupils should know that scientific knowledge is developed within the context of a range of } \\
\text { constraints that may shape it and its uses }\end{array}$ & 2.96 & 3 & 1.05 \\
\hline $\begin{array}{l}\text { Scientific knowledge and values } \\
\text { Pupils should be taught that scientists perceive and claim their work to be value free and } \\
\text { objective. This assumption is open to challenge. }\end{array}$ & 2.90 & 3 & 1.54 \\
\hline $\begin{array}{l}\text { Role of ICT } \\
\text { Pupils should be taught that Information and Communication Technology is now a } \\
\text { fundamental tool which is inherent to the practice of science }\end{array}$ & 2.78 & 2 & 1.51 \\
\hline $\begin{array}{l}\text { Range of fields in which scientific knowledge is developed } \\
\text { Pupils should be taught that scientific research is undertaken in a variety of institutions } \\
\text { by individuals who have differing social status within the scientific community. Scientists } \\
\text { generally have expertise only in one specific sub-discipline of science }\end{array}$ & 2.70 & 4 & 1.24 \\
\hline $\begin{array}{l}\text { Accountability and regulation of scientific practices } \\
\text { Pupils should be taught that issues of accountability and regulatory procedures that relate } \\
\text { to the development of scientific knowledge }\end{array}$ & 2.30 & 2 & 0.88 \\
\hline $\begin{array}{l}\text { Distinction between science and technology } \\
\text { Pupils should be taught that there is a distinction between science and technology }\end{array}$ & 2.30 & 3 & 1.36 \\
\hline $\begin{array}{l}\text { No general ideas independent of science content } \\
\text { Pupils should be taught that there are no general ideas to be taught in science. Nothing } \\
\text { can be taught about science independent of its content and knowledge of the methods, } \\
\text { institutions, and practices varies between the sciences }\end{array}$ & 2.20 & 1 & 1.51 \\
\hline
\end{tabular}




\section{Round 3}

For the third round, the number of themes under consideration was reduced. This decision was taken for two reasons. First, and importantly, if a degree of consensus was to be reached among participants, then individuals needed to be encouraged to argue more specifically for the inclusion of those ideas which could be explicitly taught. Second, research literature on the Delphi method suggests that in studies where participants were required to complete lengthy and detailed questionnaires, responses to questions towards the end of the questionnaire tend to be less fulsome and informative (Judd, 1972). There was concern among the research team that such 'participant fatigue' would result if the complete set of 28 'ideas-about-science' were included in Round 3 of the study, affecting the level of detail in responses towards the end of the questionnaire. Thus the18 top-rated themes from round 2 were used for round 3 - those with a mean $>3.60$ \&/or mode of 5 .

The final questionnaire of the Delphi study, distributed in May 2000, presented the titles, revised summaries and representative anonymised supporting statements from participants for the top rated 18 themes from Round 2, together with the mean and standard deviation calculations of the ratings for each theme. Participants were requested to rate again each theme, based on the premise that it should be explicitly taught, to justify their rating and comment on ways in which the wording of the summary might be improved to reflect the essence of each 'idea-about-science'. Mean scores and standard deviations were again calculated using the 1 to 5 response categories (table 2). 
Table 2 Round 3 Themes and their ratings from Round 3

\begin{tabular}{|c|c|c|c|}
\hline Theme Title and summary & mean & mode & S.D \\
\hline $\begin{array}{l}\text { Scientific methods and critical testing } \\
\text { Pupils should be taught that science uses the experimental method to test ideas, and, in particular, } \\
\text { about certain basic techniques such as the use of controls. It should be made clear that the outcome } \\
\text { of a single experiment is rarely sufficient to establish a knowledge claim. }\end{array}$ & 4.41 & 5 & 0.79 \\
\hline $\begin{array}{l}\text { Creativity } \\
\text { Pupils should appreciate that science is an activity that involves creativity and imagination as much } \\
\text { as many other human activities, and that some scientific ideas are enormous intellectual } \\
\text { achievements. Scientists, as much as any other profession, are passionate and involved humans } \\
\text { whose work relies on inspiration and imagination. }\end{array}$ & 4.35 & 5 & 0.72 \\
\hline $\begin{array}{l}\text { Historical development of scientific knowledge } \\
\text { Pupils should be taught some of the historical background to the development of scientific } \\
\text { knowledge. }\end{array}$ & 4.25 & 5 & 0.94 \\
\hline $\begin{array}{l}\text { Science and questioning } \\
\text { Pupils should be taught that an important aspect of the work of a scientist is the continual and } \\
\text { cyclical process of asking questions and seeking answers, which then lead to new questions. This } \\
\text { process leads to the emergence of new scientific theories and techniques which are then tested } \\
\text { empirically. }\end{array}$ & 4.22 & 4 & 0.68 \\
\hline $\begin{array}{l}\text { Diversity of scientific thinking } \\
\text { Pupils should be taught that science uses a range of methods and approaches and that there is no one } \\
\text { scientific method or approach }\end{array}$ & 4.22 & 4 & 0.71 \\
\hline $\begin{array}{l}\text { Cooperation and collaboration in the development of scientific knowledge } \\
\text { Pupils should be taught that scientific work is a communal and competitive activity. Whilst } \\
\text { individuals may make significant contributions, scientific work is often carried out in groups, } \\
\text { frequently of a multidisciplinary and international nature. New knowledge claims are generally } \\
\text { shared and, to be accepted by the community, must survive a process of critical peer review. }\end{array}$ & 4.21 & 5 & 0.79 \\
\hline $\begin{array}{l}\text { Analysis and interpretation of data } \\
\text { Pupils should be taught that the practice of science involves skilful analysis and interpretation of } \\
\text { data. Scientific knowledge claims do not emerge simply from the data but through a process of } \\
\text { interpretation and theory building that can require sophisticated skills. It is possible for scientists } \\
\text { legitimately to come to different interpretations of the same data, and therefore, to disagree. }\end{array}$ & 4.18 & 5 & 0.88 \\
\hline $\begin{array}{l}\text { Science and certainty } \\
\text { Pupils should appreciate why much scientific knowledge, particularly that taught in school science, } \\
\text { is well-established and beyond reasonable doubt, and why other scientific knowledge is more open } \\
\text { to legitimate doubt. It should be explained that current scientific knowledge is the best we have but } \\
\text { may be subject to change in the future, given new evidence or new interpretations of old evidence }\end{array}$ & 4.16 & 4 & 0.93 \\
\hline $\begin{array}{l}\text { Hypothesis and prediction } \\
\text { Pupils should be taught that scientists develop hypotheses and predictions about natural phenomena. } \\
\text { This process is essential to the development of new knowledge claims. }\end{array}$ & 4.15 & 5 & 1.00 \\
\hline $\begin{array}{l}\text { Moral and ethical dimensions in the development of scientific knowledge } \\
\text { Pupils should appreciate that choices about the application of scientific and technical knowledge are } \\
\text { not value free; they may, therefore, conflict with moral and ethical values held by groups within } \\
\text { society. }\end{array}$ & 4.06 & 5 & 1.00 \\
\hline $\begin{array}{l}\text { Observation and measurement } \\
\text { Pupils should be taught that observation and measurement are core activities of scientists; most } \\
\text { measurements are subject to some uncertainty but there may be ways of increasing our confidence in } \\
\text { a measurement. }\end{array}$ & 3.95 & 5 & 0.79 \\
\hline $\begin{array}{l}\text { Science and technology } \\
\text { Pupils should be taught that, whilst there is a distinction between science and technology, the two } \\
\text { are increasingly interdependent as new scientific discoveries are reliant on new technology and new } \\
\text { science enables new technology. }\end{array}$ & 3.83 & 4 & 0.80 \\
\hline $\begin{array}{l}\text { Specific methods of science } \\
\text { Pupils should be taught a range of techniques for data representation and analysis commonly used in } \\
\text { the sciences, with particular emphasis on those necessary for interpreting reports about science, } \\
\text { particularly those in the media. }\end{array}$ & 3.79 & 4 & 1.07 \\
\hline
\end{tabular}


Table 2 continued

\begin{tabular}{|c|c|c|c|}
\hline Theme Title and summary & mean & mode & S.D \\
\hline $\begin{array}{l}\text { Cause and correlation } \\
\text { Pupils should be taught to distinguish two types of relationship in science - causal, where there is a } \\
\text { known mechanism relating an effect to a cause; and correlational, where identified variables are } \\
\text { associated statistically but for which there is no well-established causal link. }\end{array}$ & 3.73 & 3 & 1.14 \\
\hline $\begin{array}{l}\text { The Characteristics of scientific knowledge (Features of scientific } \\
\text { knowledge) } \\
\text { Scientific knowledge aims to be general and universal. Scientific explanations are based on models } \\
\text { and representations of reality which are often simplifications of the complexity of the real world. } \\
\text { Scientific knowledge may also, in some instances, appear to be counter-intuitive. }\end{array}$ & 3.73 & 3 & 0.89 \\
\hline $\begin{array}{l}\text { Cumulative and revisionary nature of scientific knowledge } \\
\text { Pupils should be taught that much scientific knowledge is cumulative, building on that which is } \\
\text { already known. . New theories and methods are often resisted but ultimately may be accepted if } \\
\text { they are seen to have better explanatory power, parsimony or elegance. }\end{array}$ & 3.65 & 5 & 1.27 \\
\hline $\begin{array}{l}\text { The empirical base of scientific knowledge (Types of knowledge) } \\
\text { Pupils should be taught that a distinctive characteristic of scientific knowledge is that it is supported } \\
\text { by empirical evidence. Whilst the evidence for some ideas is well-established, other knowledge is } \\
\text { less secure as the empirical base is less reliable. }\end{array}$ & 3.57 & 4 & 0.92 \\
\hline $\begin{array}{l}\text { The Status of scientific knowledge (Features of scientific knowledge) } \\
\text { Pupils should be taught that science produces reliable knowledge of the natural world that can be } \\
\text { relied upon as a basis for action. }\end{array}$ & 2.79 & 3 & 1.21 \\
\hline
\end{tabular}

\section{Consensus and stability}

Further data analysis examined the degree of consensus and stability of participants' responses over Round 2 and Round 3. There is little guidance in the literature to inform decisions about the minimum percentage of panel responses for any item that might constitute consensus and it was, therefore, necessary for the research team to decide on an appropriate figure. For this Delphi study consensus was defined as a minimum of two-thirds, or 66 per cent, rating a theme as 4 or above on the Likert scale. Stability was defined as a shift of one third or less in participants' ratings between Round 2 and Round 3.

From analysis, 9 themes emerged for which there was consensus as important for inclusion in the science curriculum: Scientific methods and critical testing (87\% at $4 \& 5$ round 2, 78\% at $4 \& 5$ round 3); Creativity (70\%, 74\%); Historical development of Scientific Knowledge (74\%, 78\%); Science and Questioning (74\%, 78\%); Diversity of scientific thinking (78\%, 86\%); Analysis and Interpretation of data (78\%, $70 \%)$; Science \& Certainty (87\%, 78\%); Hypothesis and Prediction (65\%, 79\%); Cooperation and collaboration in the development of scientific knowledge (56\%, 70\%). All 17 round 3 themes have stability if the overall percentage rating at 4 and above is compared between rounds 2 and 3. If the ratings of individuals across the two rounds are compared, of the nine themes with high consensus, co-operation and collaboration shows variation in individual rating greater than $33 \%$, with $43 \%$ of participants changing their rating between round 2 and 3 by more than one level.

Participants were urged to provide detailed comments in this round to justify and explain the rating given for each theme based on the premise that it should be explicitly taught. Details are given below of justifications from round 2 and 3 for the 9 top-rated themes. 


\section{Scientific method and critical testing}

Pupils should be taught that science uses the experimental method to test ideas, and, in particular, about certain basic techniques such as the use of controls. It should be made clear that the outcome of a single experiment is rarely sufficient to establish a knowledge claim.

The highest priority was assigned to this theme over Rounds 2 and 3. Participants viewed the theme as the articulation of the 'core process on which the whole edifice of science is built' (PU03). The experimental method was said to be 'what defines science' (S06), and was the 'central thrust of scientific research' (SE02) and as such must be an essential part of the school science curriculum. One participant stated that pupils frequently formed the view that the purpose of practical work was to teach them techniques; 'they do not understand that in the research world of science, careful experimentation is used to test hypotheses' (S05). The theme was seen to provide opportunities to develop what was already a major component of the National Curriculum for science (PU01) and to highlight the importance of testing ideas as the basis of science (T02). The testing of ideas was an important issue for one participant who expressed the view that many science courses and texts labelled as 'experiments' what were in reality 'demonstrations' and therefore not a test of scientific ideas (SE01).

A warning note was sounded by one participant who, whilst supporting the importance of the theme as a 'life skill', showed concern about the procedures utilised to assess pupils' understanding in the theme:

Must consider any formal assessment to ensure that it will allow a range of responses from pupils - any claim that can be reasonablly argued from the evidence should gain credit. If assessment drives pupils towards narrow, pre-determined outcomes, then it will be impossible to teach this well. (SE06)

\section{Creativity}

Pupils should appreciate that science is an activity that involves creativity and imagination as much as many other human activities and that some scientific ideas are enormous intellectual achievements. Scientists, as much as any other profession, are passionate and involved humans whose work relies on inspiration and imagination.

Whilst it was thought by a number of participants that this theme was not easy to teach explicitly, it was nevertheless considered important that school science offered pupils opportunities to be genuinely creative 'and not just told how imaginative and clever scientists are/were' (SE03). Pupils should be encouraged to 'do science, rather than being taught about creativity' (PU03), they should be encouraged to engage in activities such as creating models/pictures to explain ideas (SE03) and to consider possible ideas to explain phenomena and test hypotheses (PU05). In countering the image of science as a 'stodgy fact-filled subject' (S03) and to 'dispel the notion of scientists as nerds' (S05), pupils should be encouraged to view science as 'fun and fascinating - and rewarding' (S03) and to appreciate that 'creative science is more exciting a pursuit than most' (S05). In emphasising the importance of creativity in school science, one participant made the point that:

All too often students are turned off science by the large amount of rote learning involved. Indeed some students move to the arts/humanities because they find there a 
far greater potential to exercise their creativity. This is a crucially important message to communicate. (PS05)

Whilst offering strong support for the inclusion of the theme in the school science curriculum, one participant expressed concern that making the teaching of the theme explicit might be 'counter-productive if it discourages efforts to make sure it infuses the whole brew of school science' (PU01).

\section{Historical Development of Scientific Knowledge}

Pupils should be taught some of the historical background to the development of scientific knowledge.

There was widespread agreement among the panel that this theme was capable of being taught explicitly and was an important component of pupils' learning in science. The teaching of the history of science had the potential to facilitate an appreciation of developments in science, as well as the ways and extent to which such developments had been affected by the demands and expectations of society at different points in history (PS05).

The theme was seen as an antidote to rote learning, as it emphasised science as a human activity, for example, 'through it even young pupils can come to understand personal aspects of scientific enquiry' (SE04). However, it was not only important in adding 'human interest' to science lessons, but in fostering a realisation of the ways in which ideas have been tested and developed in the past and the ways in which this has informed continued developments in science (SE05). It was suggested that for pupils who lacked interest in science or experienced difficulties in learning aspects of science, adopting a historical perspective may be 'a hook to catch their interest' (PS07), but a warning note was sounded by one member of the panel who made the point that:

Badly told history of science - traditional stories of mythic heroes etc - undermine the entire enterprise. Someone needs to start rewriting the storybooks. (PU04)

There was general agreement among the panel that whilst the theme summary captured the essence of the typical statements it might be extended to provide clearer guidance for teachers. This might include guidance on the selection of ideas, the clear specification of the criteria for the selection of ideas and some indication of the contested nature of the history of science (PU05; PS05; SE02; PS02).

\section{Science and questioning}

Pupils should be taught that an important aspect of the work of a scientist is the continual and cyclical process of asking questions and seeking answers, which then lead to new questions. This process leads to the emergence of new scientific theories and techniques which are then tested empirically.

There was agreement among participants that questioning was 'part and parcel of the process of science' (SE01), it reinforced the notion that 'science is characterised by unfinished business' (PU01) and emphasised the importance of continual testing and evolution of understanding (S06). It was stressed that the explicit teaching of questioning should form an integral part of teaching in science - 'the more pupils question, the more they understand the thinking behind the scientific knowledge' 
(T02). As the following comment shows, the value of engagement in the cyclic process of questioning and seeking answers was not limited to science, but has wider application in the curriculum:

Questioning is the engine of human development and is not specific to science. While knowledge is obviously important, it is given far too central a place in our education system. Although it is much easier to grade students in terms of their knowledge, knowledge by itself is useless unless it leads to the forming of new and pressing questions. Inculcates an attitude that applies to all areas. (PS05)

\section{Diversity of scientific thinking}

Pupils should be taught that science uses a range of methods and approaches and that there is no one scientific method or approach.

The importance of this theme lay in the potential to provide pupils with first hand experience of the breadth of scientific activity (PU03). It was seen to 'help nip scientism in the bud' (PU04), indicating to pupils that the world might be explored through a range of means. The theme offered opportunities to develop an understanding that 'science is not rigid - a number of methods may be used to solve the same problem' (PU06). It encouraged teachers to 'get away from the simplistic notions of how science is done' (SE02), to enable pupils to select the most appropriate method for the problem being addressed and 'the degree of confidence required of the outcome' (SE02). Another benefit to pupils was the building of a 'tool kit' of scientific methods to test their ideas, together with a growing awareness that in some circumstances scientists need to develop new methods, or adapt an old one, to test a particular idea (SE03).

Whilst accepting the importance of the theme, one participant was keen to stress the teaching of common elements of scientific methods:

Different disciplines have different methodologies and approaches, but all in the end rely upon observation, theorising, experiments, testing, refinement of theory leading to acceptance or rejection of theory, so they have something on common. (S05)

In contrast to this last statement, one member of the panel wished to include in the theme mention of those aspects of science for which experiments were not appropriate or realistic, for example:

Cosmology, most geology, most histology, most taxonomy are impossible to look at with experiment; in some medical research it is unethical to undertake possible experiments. (PU05)

The majority of participants expressed the view that the theme summary captured the essence of the intrinsic concepts. It was said, for example, to be, 'a good summary of a rather slippery point' (PS02). Two participants felt that more explanation and guidance would be needed for teachers in developing the theme with pupils (S06; PS05) and one participant called for the substitution of the word 'method' in the summary with 'enquiry' or 'investigation'. 


\title{
Analysis and interpretation of data
}

Pupils should be taught that the practice of science involves skilful analysis and interpretation of data. Scientific knowledge claims do not emerge simply from the data but through a process of interpretation and theory building that can require sophisticated skills. It is possible for scientists legitimately to come to different interpretations of the same data, and therefore, to disagree.

There was particular emphasis in participants' justifications on the second part of the summary statement. It was said, for example, that, 'it is crucial to know that scientific data does not stand by itself, but can be variously interpreted' (PS01). Pupils need to be taught that data do not 'speak by themselves - instead they require other layers of interpretation (PS05). An understanding that scientists may legitimately come to different interpretations of the same data was thought to be an important concept for all pupils, not only those individuals who might later pursue a science related career, but also for those pupils who do not' (PS05). Three participants expressed the view that the analysis and interpretation of data would be more effectively taught if pupils were encouraged to generate and use their own data (SE03). This view was supported and developed by another member of the panel who offered the following justification for the inclusion of the theme in the science curriculum:

\begin{abstract}
...it is important that students do their own research - then, just like practising scientists, they will be interested in the analysis and interpretation of data. Such explorations by a number of groups in the same class could well lead to different interpretations. The conflicting claims of opposing pressure groups could be used to highlight the data in different ways. It is important for students to be more critical of science and to question the results - this theme encourages a more objective view of science and scientists. (PU06)
\end{abstract}

\section{Science and Certainty}

Pupils should appreciate why much scientific knowledge, particularly that taught in school science, is well established and beyond reasonable doubt, and why other scientific knowledge is more open to legitimate doubt. It should also be explained that current scientific knowledge is the best we have but may be subject to change in the future, given new evidence or new interpretations of old evidence.

There was agreement among members of the panel that the 'provisional' nature of science, implicit in this theme, was an 'extremely important concept' (S05) in school science. It was important for pupils to appreciate that where there appears to be right answers in school science, this is because 'questions are asked which are capable of quantitative determination' (S05). In contrast to this, questions asked by scientists working in the field were frequently those which could not be answered at present, whether because the questions were too complicated to be amenable to sensible experimentation, or simply because experiments have yet to be undertaken - for example GM foods, BSE (S05).

The theme had the advantage of highlighting the contemporary nature of science, suggesting that there was more to be discovered - a concept considered important in encouraging pupils to consider a career in science (PU06). However, two participants expressed concern that in overemphasising the tentative nature of much scientific knowledge pupils might be led to feel that science is 'about something, but they do not know what' (T05). It was also said that such an emphasis, for the vast majority of 
people was not relevant. It was thought to of greater importance for teachers to explain that 'there are certain areas where we remain largely ignorant, e.g. how the brain works' (S07).

One participant expressed reservations about the explicit teaching of the theme, the point being that pupils would require specialist knowledge of science in order to understand areas of current uncertainty in science and there was a danger that 'this may push teachers towards transmission of facts’ (SE03)

There was some disagreement among members of the panel about the wording of the summary. As the comment below shows, one participant felt that the theme summary conveyed a message that was 'somewhat sophisticated' and might be difficult to absorb into the current school science curriculum:

At one level it requires the child not to question school science; at another to view 'frontier' science as not beyond question. Where does the boundary lie between those two types of science? (PS05).

\section{Hypothesis and prediction}

Pupils should be taught that scientists develop hypotheses and predictions about natural phenomena. This process is essential to the development of new knowledge claims.

This theme was described variously as 'essential' (SE01) and 'the very basis of science' (S03). It was essential for pupils to understand that making predications and collecting evidence to test them is central to testing hypotheses and developing explanations (SE05). The formulation of hypotheses and testing predictions were said to be 'the spark that ignites any scientific activity' (PU06) and was as relevant for pupils in science lessons as it was for the scientist in the laboratory.

The link between hypotheses and predictions and creativity in science was made by a number of participants. In this the theme was described as an antidote to 'just fact collecting' (S07) and showed that science was concerned more with 'testable theory' than with 'fact' (PU04; T05; S02). One participant stressed the value of this theme in the wider context of pupils' education by stating that:

This has many applications outside science - it is a good prescription for thinking critically about almost any topic. Thus it encourages an attitude that should be of help, not only to science students, but also those with no intention of pursuing science. (PS05)

To ensure the effective teaching of this theme, one participant thought it advisable to clarify the meaning of the term 'scientific hypothesis' used in the theme summary, as there was good research evidence to show that 'students have difficulty in being clear what is meant by the term' (SE02) 


\section{Cooperation and collaboration in development of scientific knowledge}

Pupils should be taught that developments in science are not the result of individual endeavour. They arise from group activity and collaboration, often of a multidisciplinary and international nature. New knowledge claims are generally shared and, to be accepted by the community, must survive a process of critical peer review.

This theme offered pupils a useful perspective on scientific activity, said to be 'too often viewed as the retreat of the lone genius' (PS05). It was considered important that teaching of the theme stressed the social process in science as this was an aspect that was too often overlooked in school science (PS05). The inclusion of the peer review process in this theme was thought to be important, as it showed that scientists 'go one step further in being reviewed by their peers, so adding to the validity of new scientific knowledge' (PU06). The theme was said to be 'fundamental to understanding both the contingency and the reliability of knowledge' (PU04) and in evaluating new knowledge claims, it was important that pupils gained an understanding of the variety of communities in which scientific knowledge is developed (PU01). Participants generally felt that the explicit teaching of the theme was relatively straightforward, best achieved through encouraging pupils to engage in collaborative work in science lessons and possibly 'to get international peer review through the Internet - well in the future anyway' (SE03). However, one participant was concerned that an emphasis on collaboration in school science should not subsume the social process of 'criticism, disagreement and competition' (PS07).

\section{Related and similar themes}

Although the themes have been presented as discreet entities, it is evident from the comments of the participants that many perceived distinct interrelationships between the themes. In order to express this interrelationship, all the participants' comments on Round 3 statements were scrutinised for expressions of links. The resulting map (figure 3) shows the nature and frequency of identified links between the round 3 themes, with the top rated themes highlighted.

This 'map' illustrates the clear links participants had identified between major themes, indicating an expectation that, although the themes should be taught explicitly, they would not be addressed in isolation. It is notable that the eight highly rated themes all have expressed links with each other and multiple links to other themes - presenting some interesting issues in planning for teaching. 'Science and technology' and 'moral and ethical dimensions in the nature of scientific knowledge' are seen as discrete entities, perhaps implying that these themes are qualitatively different from the interrelated strands at the heart of the nature of science. 
Figure 3 Map of 'ideas-about-science’ themes

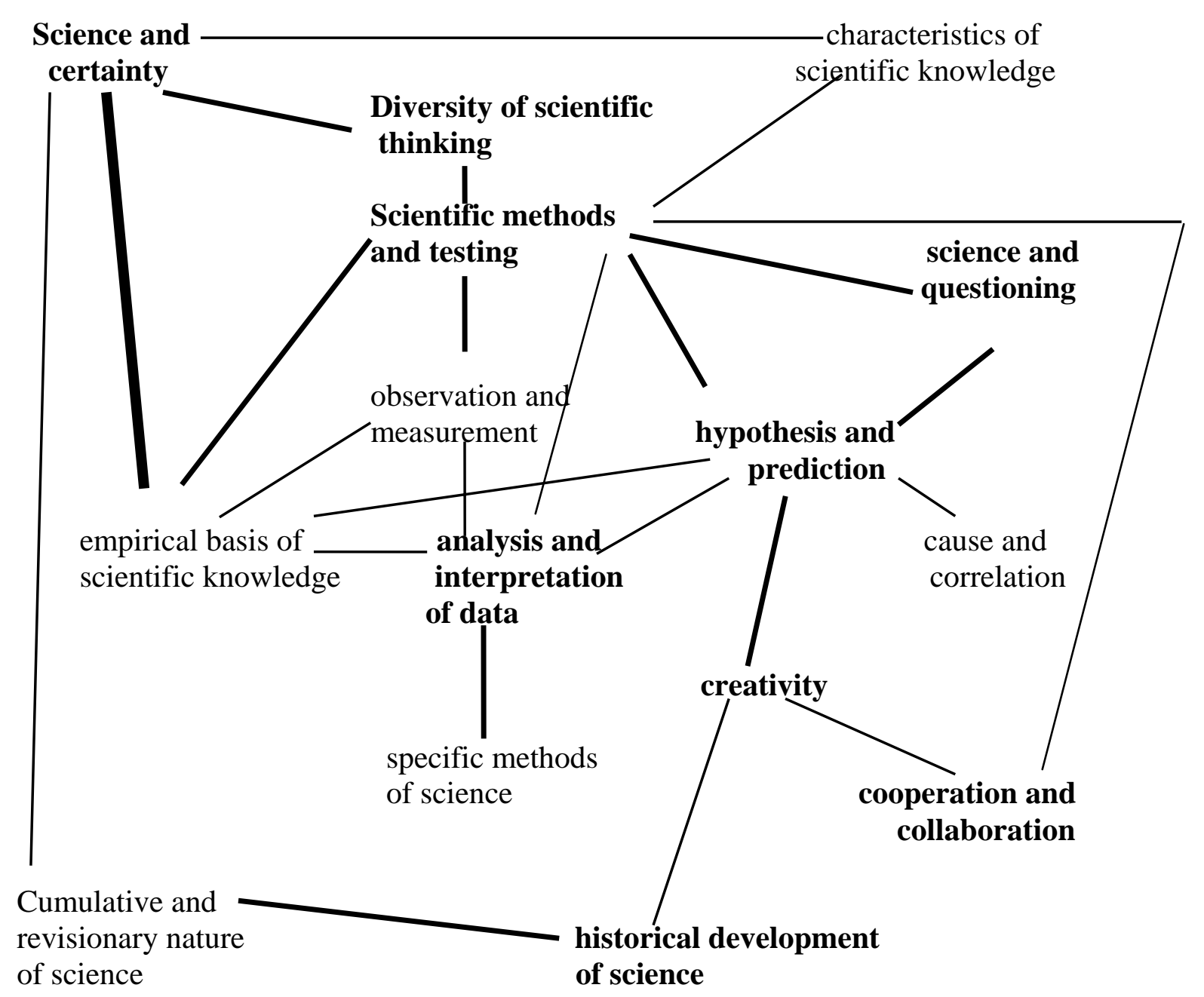

Science and

Moral and ethical dimensions

Technology

in the development of scientific knowledge

1 or 2 explicit comments The top rated themes are in bold

3 to 5 explicit comments

10 explicit comments

\section{Discussion and Conclusions}

The survey of a panel of diverse experts has produced results that raise some fundamental classroom-based issues about curriculum design, instruction and curriculum implementation. First, we see the findings of this work as a significant contribution to the debate that currently surrounds the teaching of the nature of science in schools and the nature of the account that should be offered. Whilst, we 
would not claim that it is comprehensive, it is the only systematic attempt, of which we are aware, to determine what an 'expert' community might deem acceptable as a vulgarised account of the nature of science and the practices of the scientific community.

Second, some of our themes bear similarity to those already extant in current_National Curricula. McComas and Olson (1998) have analysed 8 of these documents from the USA, UK, Canada, New Zealand and Australia for the statements about what components of the nature of science should be taught. Table 3 beneath shows a tentative comparison of the most prevalent ideas about science to be found in those documents, i.e. found in 6 or more documents and those emerging from this study.

This comparison suggests that whilst there is some overlap, there are other components which may be missing from both methods of determining what should constitute an appropriate curriculum for teaching about the nature of science. In short, and perhaps not surprisingly, no one method can provide a universal solution as to what should be the essential elements of a contemporary science curriculum.

However, the components that emerge from both of these studies do pose a significant challenge to curriculum designers and policy makers. For instance, the treatment of the history of science has been notable by its absence from the science curricula of the past 100 years - principally because it is seen of little value to the education of the future scientist. Consequently, there exists little knowledge amongst the body of science teachers of effective strategies for its teaching and they, themselves, unlike other disciplines, remain relatively ignorant of the history of the subject themselves. Likewise, there is little knowledge of how to communicate that science is a creative activity. As for the diversity of scientific thinking, few curricula have recognised the fundamental division that Rudolph (2000) makes between developing models and empirical testing - largely the preserve of the physical and chemical sciences - and, in contrast, the process of historical reconstruction whether it be a phylogenetic mapping of the various species, developing cosmological models of the past universe, or mapping the climate changes on Earth. In the latter, the immediate goal is not the development of a model but constructing a reliable record of past events. 
Table 3: Comparison of themes emerging from this study with those from McComas and Olson's study of national standards

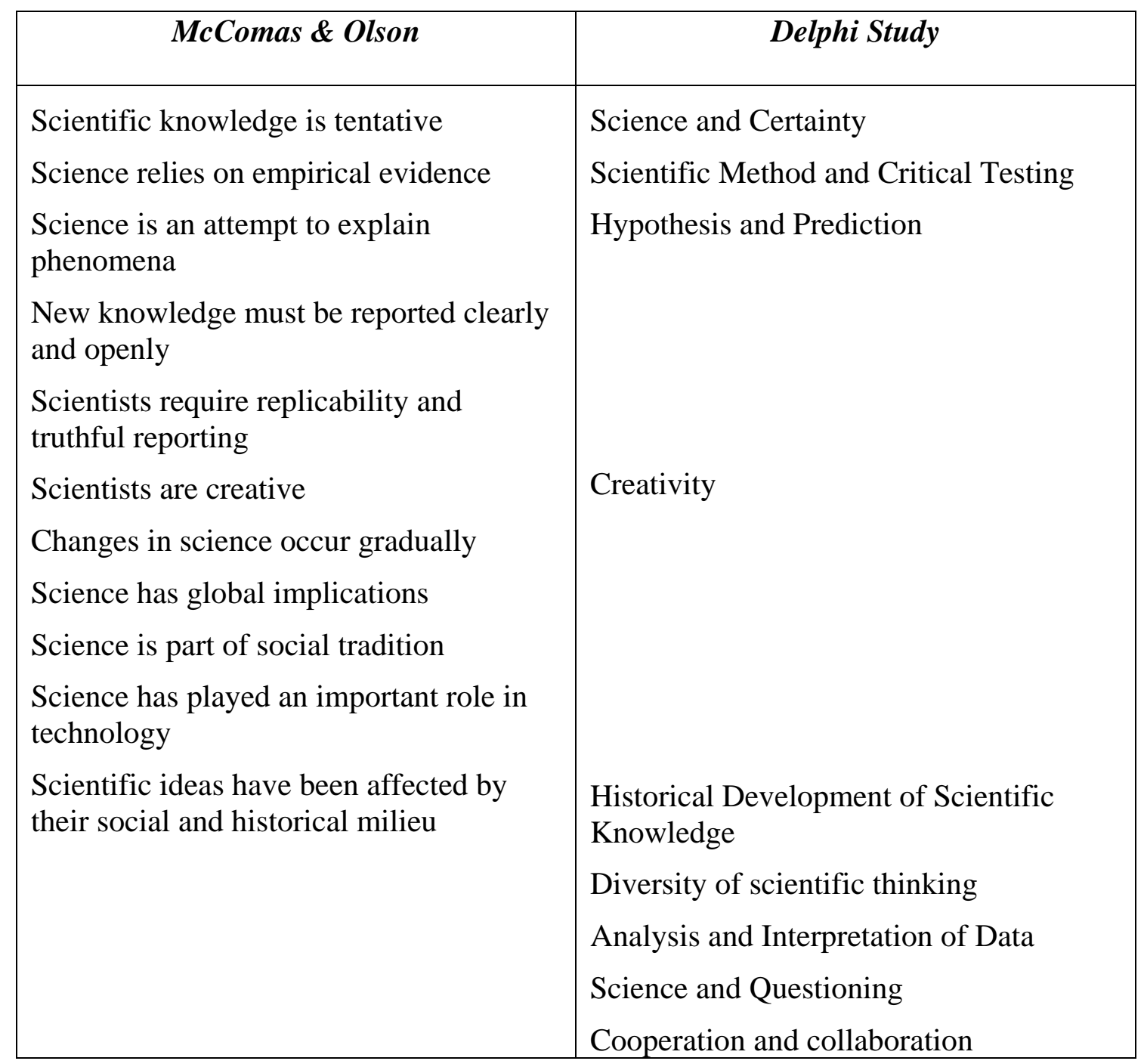

Taken together, we would suggest that these data strengthen the case that we (Duschl, 1990; Millar and Osborne, 1998) and others have made for school science to pay more attention to explicitly teaching about the nature of science, its epistemic base and the significance of its cultural achievements.

Many of the themes emerging fall under the umbrella of the 'Methods of Science' (Experimental Methods and Critical Testing, Creativity, Science and Questioning, Diversity of Scientific Method, and Analysis and Interpretation of Data) fall are all components of the Methods of Science). Two (Historical Development of Scientific Knowledge and Science and Certainty) are aspects of the Nature of Science and within the top rated themes there is little emphasis on the Institutions and Social Practices of Science (cooperation and collaboration). Whilst, this can be explained in part, by the fact that many participants saw aspects of the institutional and social practices subsumed within the other themes, it invites questions why so many of the ideas of contemporary scholarship about the nature of science is absent. Neither, for 
instance, do any of the sets of themes, either these resulting from the Delphi study or the National Curricula documents place much emphasis on the role of theory, explanation or models. They do not, for instance, represent well a more contemporary view of science such as that offered by Giere (1991) who portrays science as a multidimensional interaction between the models of scientists, empirical observation of the real world and their predictions. However, the question to our participants was phrased as 'what, if anything, should be taught about the methods of science/the nature of scientific knowledge/the institutions and social practices of science? In short, we were asking for a minimalist and essentialist description. Our data are the answer of this community and suggests that the omissions were simply regarded as too complex or too contentious for inclusion. What they do offer, however, is a vulgarised account which a) our research would suggest would be acceptable to the overwhelming majority of those engaged in science, its practice and its communication, and b) an account which is considerably more sophisticated than the naïve notions promulgated by the teaching of science in many classrooms across the globe at present.

More fundamentally, the question now arises as to how these statements can be operationalised into teaching strategies, activities and material to support their teaching. One challenge is how will these themes become part of the instructional sequence. To what extent, for instance, can these themes be taught directly as part of discrete lessons or should they permeate all science lessons? Even those that might be considered integral components of the existing curriculum such as analysis and interpretation of data are often poorly covered and research would suggest poorly understood by pupils (Gott \& Johnson, 1996; Watson \& Wood-Robinson, 1998). Whilst inquiry based approaches, investigations or practical work will certainly address many of the themes in the 'methods of science' category, unless there is some careful mediation on the part of the teacher across lessons to frame explicitly the process and outcomes of these activities and to draw attention to their generic features, many of these aspects may only be glimpsed partially by students.

Moreover, additional and new strategies will be needed to address aspects of the 'nature of science' or 'institution and social processes of science'.

It is such problems which the current phase of work with 12 teachers (3 grade 6, 4 grade 9 and 4 grade 10) is now exploring. With these teachers we are attempting to see how the themes can become an integral part of their teaching. To this end, we and the teachers have been developing materials and strategies and meeting regularly to share experiences during the course of the year. As researchers, we have been videoing a selection of the lessons, gathering field notes, interviewing teachers and assessing the progress of their pupils. We hope, therefore that this work, which we will be reporting next year, will assist in making the teaching of the nature and ideas about science more of a reality than rhetoric.

\section{Acknowledgement}

This study was supported by the UK Economic and Social Science Research Council as part of a Teaching and Learning Research Programme Network (grant number L139251003) 


\section{References}

Abd-El-Khalick, F., \& Lederman, N. (2000). Improving science teachers' conceptions of the nature of science: a critical review of the literature. International Journal of Science Education, 22(7), 665-702.

Alters, B. J. (1997). Whose Nature of Science? Journal of Research in Science Teaching, 34(1), 39-55.

American Association for the Advancement of Science. (1989). Project 2061: Science for All Americans:. Washington: DC: AAAS.

American Association for the Advancement of Science. (1993). Benchmarks for Scientific Literacy. Washington: DC: AAAS.

American Association for the Advancement of Science. (1998). Blueprints for Reform: Science, Mathematics and Technology Education. New York: Oxford University Press.

Blair, S. and Uhl, N.P. (1993) Using the Delphi method to improve the curriculum The Canadian Journal of Higher Education 23, 3, 107-128

Brickhouse, N. (1991). Teachers' Beliefs about the Nature of Science and Their Relationship to Classroom Practice. Journal of Teacher Education, 41(3), 5362.

Brooks, K.W. (1979) Delphi Techniques: Expanding Applications. North Central Association Quarterly, 53, 3, 377-385

Brush, S. G. (1969). The Role of History in the Teaching of Physics. The Physics Teacher, 23, 11-19.

Claxton, G. (1991). Educating the Enquiring Mind: the Challenge for School Science: Harverster: Wheatsheaf.

Clayton, M.J. (1997). Delphi: a technique to harness expert opinion for critical decision-making tasks in education. Educational Psychology, 17(4), 373-386

Cochran, S. W. (1983) The Delphi Method: Formulating and Refining Group Judgements. Journal of Human Sciences . 2(2), 111-17

Collins, H. (2000). On Beyond 2000. Studies in Science Education, 35, 169-173.

Cyphert, F. R. and Gant, W. (1971). The Delphi Technique: A Case Study. Phi Delta Kappan, 52(5), 272-273.

Dailey, A. L. and Holmberg, J. C. (1990) Delphi - A Catalytic Strategy for Motivating Curriculum Revision by Faculty. Community/Junior College Quarterly Review: 14, 129-136.

Delbecq, A. L. and Van de Ven, A. H. and Gustafson, D. H. (1975) Group Techniques for Program Planning. Glenview, IL. Scott Foresman

Donnelly, J. (2001). Contested terrain or unified project? 'The nature of science' in the National Curriculum for England and Wales. International Journal of Science Education, 23(2), 181-195.

Doyle, C. (1993) The Delphi Method as a Qualitative Assessment Tool for Development of Outcome Measures for Information Literacy. School Library Media Annual v11, 132-144

Driver, R., Leach, J., Millar, R., \& Scott, P. (1996). Young People's Images of Science. Buckingham: Open University Press. 
Duschl, R., Hamilton, R., \& Greudy, R. (1990). Psychology and Epistemology: Match or mismatch when applied to science education? International Journal of Science Education, 12(3), 230-243.

Duschl, R. A. (1990). Restructuring Science Education. New York: Teachers College Press.

European Commission. (1995). White paper on education and training: Teaching and learning-Towards the learning society (White paper ). Luxembourg: Office for Official Publications in European Countries.

Fuller, S. (1997). Science. Buckingham: Open University Press.

Giere, R. (1991). Understanding Scientific Reasoning (3rd ed.). Fort Worth, TX: Holt, Rinehart and Winston.

Gott, R., \& Johnson, P. (1996, April, 1996). Children's Use of Evidence in Science Investigations: What are the implications for Science Education? Paper presented at the Annual Meeting of the American Educational Research Association, New York.

Häussler, P., Frey, K., Hoffman, L., Rost, J. and Spada, H. (1980) Education in Physics for Today and Tomorrow: Results of a curricular Delphi study. University of Kiel. FRG. Kiel.

Hodson, D. (1993). Philosophic Stance of Secondary School Science Teachers, Curriculum Experiences, and Children's Understanding of Science. Interchange, 24(1 \& 2), 41-52.

Horton, R. (1967). African Traditional Thought and Western Science. Africa, 37, ?? Irwin, A. (1995). Citizen Science. London: Routledge.

Jenkins, E. (1997). Towards a Functional Public Understanding of Science. In R. Levinson \& J. Thomas (Eds.), Science Today: Problem or Crisis? (pp. 137150). London: Routledge.

Jenkins, E. (1998). Scientific and Technological Literacy for Citizenship: What can we learn from the research and other evidence? Available: http://www.leeds.ac.uk/educol/documents/000000447.doc.

Judd, R. C. (1971) Delphi Decision Methods in Higher Education Administration, Paper presented at the $12^{\text {th }}$ American meeting of The Institute of Management Sciences, Detroit.

Koulaidis, V., \& Ogborn, J. (1995). Science teachers' philosophical assumptions: how well do we understand them? International Journal of Science Education, 17(3), 273-282.

Kuhn, T. E. (1970). The Structure of Scientific Revolutions (2cnd ed.). Chicago: University of Chicago Press.

Latour, B. (1985). Science in Action: How to Follow Scientists and Engineers through Society. Cambridge, MA: Harvard University Press.

Laudan, L. (1990). Science and Relativism: Some Key Controversies in the Philosophy of Science. Chicago: University of Chicago Press.

Laudan, L., Donovan, A., Laudan, R., Barker, P., Brown, H., Leplin, J., Thagard, P., \& Wykstra, S. (1986). Scientific Change: Philosophical Models and Historical Research. Synthese, 69(141-223).

Lederman, N. G., \& Zielder, D. L. (1987). Science teachers' conception of the nature of science: Do they really influence teaching behaviour? Science Education, 71(5), 721-734.

Martorella, P. H. (1991) Consensus Building Among Social Educators: A Delphi Study. Theory and Research in Social Education. 19 (1), 83-94. 
Matthews, M. R. (1994). Science Teaching: The Role of History and Philosophy of Science. New York: Routledge.

McComas, W. F., \& Olson, J. K. (1998). The Nature of Science in International Science Education Standards Documents. In W. F. McComas (Ed.), The Nature of Science in Science Education: Rationales and Strategies (pp. 4152). Dordrecht: Kluwer.

Millar, R. (1996). Towards a science curriculum for public understanding. School Science Review, 77(280), 7-18.

Millar, R. (1997). Science Education for Democracy. In R. Levinson \& J. Thomas (Eds.), Science Today (pp. 87-101). London: Routledge.

Millar, R., \& Osborne, J. F. (Eds.). (1998). Beyond 2000: Science Education for the Future. London: King's College London.

Murry, J. W. and Hammons, J. O. (1995) Delphi: A Versatile Method for Conducting Qualitative Research. The Review of Higher Education. 18(4), 423-436.

National Academy of Science. (1995). National Science Education Standards. Washington, D.C.: National Academy Press.

Nelkin, D. (1975). The political impact of scientific expertise. Social Studies of Science, 5, 37.

Osborne, J., \& Simon, S. (1996). Primary Science: Past and Future Directions. Studies in Science Education, 27, 99-147.

Osborne, J. F., \& Collins, S. (2000). Pupils' and Parents' Views of the School Science Curriculum . London: King's College London.

Osborne, J. F., Driver, R., \& Simon, S. (1996). Attitudes to Science: A Review of Research and Proposals for Studies to Inform Policy Relating to Uptake of Science. . London: King's College London.

Osborne, J.F. (in press). Promoting Argument in the Science Classroom: A Rhetorical Perspective. Canadian Journal of Science and Mathematics Research

Reichenbach, H. (1938). Experience and Prediction. Chicago: University of Chicago.

Rudolph, J. L. (2000). Reconsidering the 'nature of science' as a curriculum component. Journal of Curriculum Studies, 32(3), 403-419.

Shulman, L. S. (1986). Those who understand: Knowledge growth in teaching. Educational Researcher, 15, 4-14.

Smith, K. S. and Simpson, R. D. (1995) Validating Teaching Competencies for Faculty Members in Higher Education: A National Study Using the Delphi Method. Innovative Higher Education. 19 (3), 223-234.

Smith, M., Lederman, N. G., Bell, R., McComas, W. F., \& Clough, M. (1997). How Great is the Disagreement about the Nature of Science: A response to Alters. Journal of Research in Science Teaching, 34(10), 1101-1103.

Taylor, C. (1996). Defining Science: A Rhetoric of Demarcation. Madison: Wisconsin: The University of Wisconsin Press.

Turner-Bissett, R. (1999). The Knowledge Bases of the Expert Teacher. British Educational Research Journal, 25(1), 39-56.

Uhl, N. P. (1983). Using the Delphi Technique in Institutional Planning. New Directions for Institutional Research, 37, 81-94.

Watson, R., \& Wood-Robinson, V. (1998). Learning to Investigate. In M. Ratcliffe (Ed.), ASE Guide to Secondary Science Education (pp. 84-91). Cheltenham: Stanley Thornes.

Whitman, N. I. (1990). The Delphi Technique as an Alternative for Committee Meetings. Journal of Nursing Education, 29 (8), 377-379. 